\title{
SISTEM PENDUKUNG KEPUTUSAN PENERIMA ZAKAT DENGAN METODE SIMPLE ADDITIVE WEIGHTING
}

\author{
Asni Furoida, Sutikno \\ Departemen Ilmu Komputer/Informatika, Fakultas Sains dan Matematika, Universitas Diponegoro \\ Jl. Prof. Soedarto, SH, Tembalang Semarang - 50275, Jawa Tengah, Indonesia \\ tik@undip.ac.id
}

\begin{abstract}
Abstrak - Zakat in Islam is a cleansing of wealth by setting aside some of it and then being distributed to mustahik. Zakat management becomes important thing to do in Indonesia because the majority of population in Indonesia is Muslim. One of zakat management institutions in Indonesia is Badan Amil Zakat Nasional (BAZNAS) Semarang. Zakat distribution from muzaki to mustahik in BAZNAS Semarang is distributed by utilization program, such as the Semarang Cerdas programs that focus on the distribution of funds in the field of education. One of Semarang Cerdas program provides educational assistance for orphans, du'afa and disadvantaged students that aim to alleviate the cost of education. The problem encountered is that the election of mustahik is still being done manually. This method often leads to miscalculations that result in less accurate of mustahik election. There are five criterias in determining mustahik; the status of children, family income, family responsibilities, house index, and ownership of property. The use of simple additive weighting method was chosen because this method is able to select the best alternative by calculating and considering the weight value of each criterion, and then proceed to determine the process of ranking the mustahik based on the amount of available fund. The test results showed that the accuracy of the new system with the old system of BAZNAS Semarang is $81 \%$, so it could be concluded that this zakat recipient decission support system is able to process the mustahik election quickly and efficiently.
\end{abstract}

Keywords - Mustahik, Decision Support Systems, Simple Additive Weighting

\section{PENDAHULUAN}

Memasuki era globalisasi masa kini, pemanfaatan sistem informasi semakin berkembang. Salah satunya sistem pengambilan keputusan (SPK) atau Decission Support System (DSS) yang merupakan bagian sistem informasi untuk memudahkan pengambilan keputusan baik untuk jangka pendek, menengah atau panjang. Sejumlah keputusan yang diambil tidak hanya berhubungan dengan bisnis, namun juga dapat berhubungan dengan bidang-bidang lain, seperti bidang agama.

Zakat dalam agama Islam merupakan pembersih dari harta kekayaan yaitu dengan menyisihkan sebagian harta kekayaan bila telah mencapai waktu dan besaran jumlahnya. Selain membersihkan dari harta kekayaan, zakat juga meringankan beban mustahik (orang yang berhak menerima zakat). Di Indonesia yang mayoritas pemeluk agama Islam, masalah zakat menjadi hal yang penting untuk dimaksimalkan pengelolaannya yang nantinya berguna untuk mengatasi masalah kemiskinan.

Menurut undang-undang nomor 23 tahun 2011 tentang pengelolaan zakat, menyatakan bahwa pengelolaan zakat dilakukan oleh badan amil zakat nasional dan lembaga amil zakat. Badan Amil Zakat Nasional (BAZNAS) merupakan organisasi pengelola zakat yang dibentuk oleh pemerintah. BAZNAS berkedudukan di tiap-tiap kabupaten/ kota, salah satu BAZNAS yang berdiri di tingkat kota adalah BAZNAS kota Semarang. Penyaluran zakat BAZNAS kota Semarang didistribusikan pada tiap program pendayagunaan, diantaranya Semarang Makmur, Semarang Cerdas, Semarang Sehat, Semarang Peduli, dan Semarang Taqwa. Semarang Cerdas berfokus pada penyaluran zakat pada bidang pendidikan, salah satu dari program Semarang Cerdas adalah memberi bantuan pendidikan kepada anak yatim dan du'afa, siswa yang kurang mampu yang bertujuan membantu meringankan beban biaya pendidikan mereka.

Masalah yang sering dijumpai adalah cara dalam pemilihan mustahik yang masih menggunakan cara manual, sehingga sering menimbulkan masalah seperti lamanya proses pemilihan dan terjadinya salah hitung sehingga menimbulkan kurang akuratnya hasil seleksi mustahik. Selain itu, tidak tersedianya akses informasi untuk melihat mustahik yang telah masuk kedalam daftar penerima zakat, mengakibatkan mustahik yang sudah menerima zakat dapat menerima bantuan lebih dari satu kali dalam setahun. Untuk itu perlu di buat suatu sistem yang dapat membantu pengelola zakat dalam penyaluran kepada penerima zakat yaitu sistem pendukung keputusan. Penelitian yang berhubungan dengan sistem pendukung keputusan ini telah di lakukan yaitu dengan metode Multi Factor Evaluation Process (MFEP) [1], metode fuzzy [2], metode Analytic Network Process [3] dan metode Fuzzy C-Means [4]. Pada penelitian ini metode yang di gunakan yaitu metode Simple Additive Weighting (SAW). 
Telah banyak penelitian yang dilakukan dengan memanfaatkan metode Simple Additive Weighting (SAW) sebagai penyelesaiannya. Seperti yang dilakukan Heri Sulistyo, dalam penelitiannya yang berjudul sistem pendukung keputusan untuk menentukan penerima beasiswa di SMA Negeri 6 Pandeglang, dari penelitian ini diambil kesimpulan bahwa dengan metode SAW, proses pemilihan dapat dilakukan dengan cepat dan dapat mengurangi kesalahan dalam pemilihan penerima beasiswa [5]. Metode SAW juga digunakan dalam penentuan kelayakan pemberian kredit pinjaman pada nasabah BRI, dalam penelitian ini diambil kesimpulan bahwa sistem tersebut dapat memberikan alternatif terbaik dalam pengambilan keputusan [6]. Diharapkan dengan sistem ini dapat mempermudah BAZNAS kota Semarang dalam proses pemilihan penerima zakat, sehingga proses dapat dilakukan secara cepat dan efisien.

\section{TINJAUAN PUSTAKA}

\section{A. Pengertian Zakat}

Zakat merupakan sejumlah harta tertentu yang diwajibkan oleh Allah untuk diserahkan kepada orang yang berhak dengan berbagai syarat. Zakat hukumnya wajib (fardhu) bagi muslim yang telah memenuhi syarat. Dasar hukum dari zakat telah tercantum dalam Al-Quran surat At -Taubah ayat 103 [7].

\section{B. Penerima Zakat}

Dalam penelitian ini, ruang lingkup golongan penerima zakat adalah fakir miskin. Kriteria dari fakir miskin menurut pemerintah dalam keputusan menteri sosial republik Indonesia nomor 146/ HUK/ 2013 tentang penetapan kriteria dan pendataan fakir miskin dan orang tidak mampu yaitu [8]:

1. Tidak mempunyai sumber mata pencaharian atau mempunyai sumber mata pencaharian tetapi tidak mempunyai kemampuan memenuhi kebutuhan dasar

2. Mempunyai pengeluaran sebagian besar digunakan untuk memenuhi konsumsi makanan pokok dengan sangat sederhana

3. Tidak mampu atau mengalami kesulitan untuk berobat ke tenaga medis, kecuali puskesmas atau yang disubsidi pemerintah

4. Tidak mampu membeli pakaian satu kali dalam setahun untuk setiap anggota rumah tangga

5. Mempunyai kemampuan hanya menyekolahkan anaknya sampai jenjang pendidikan sekolah lanjutan tingkat pertama

6. Kondisi rumah yang memprihatinkan seperti luas rumah kurang dari $8 \mathrm{~m}^{2}$ / orang, kondisi lantai terbuat dari tanah/kayu, dinding rumah terbuat dari bambu/ kayu/ tembok kualitas rendah, penerangan yang kurang.

\section{Sistem Pendukung Keputusan}

Sistem pendukung keputusan (SPK) adalah suatu sistem yang ditujukan untuk mendukung manajemen dalam proses pengambilan keputusan masalah yang terstruktur maupun tidak terstruktur dan dengan kriteria yang kurang jelas. SPK bertujuan untuk menyuguhkan piranti interaktif yang memungkinkan pengambilan keputusan untuk menganalisa menggunakan model penyelesaian yang tersedia [9]. Sistem Pendukung Keputusan bukanlah alat penentu keputusan. SPK hanya membantu dalam pengambil keputusan dengan memberikan alternatif-alternatif terbaik berdasarkan hasil komputasi, dan untuk penentuan keputusan diserahkan sepenuhnya kepada pengguna. SPK hanya membantu memberikan hasil yang efektif dan efisien.

Komponen-komponen yang ada pada SPK antara lain [10], yaitu :

1. Subsistem Manajemen Data (Data Management)

Subsistem ini memasukkan satu basis data yang berisi data yang relevan untuk situasi dan dikelola oleh Data Base Management System (DBMS).

2. Subsistem Manajemen Basis Data Model (Model Management)

Subsistem ini merupakan paket perangkat lunak yang memasukkan model keuangan, ilmu manajemen, atau model kuantitatif lain yang memberikan kapabilitas analitik dan manajemen perangkat lunak yang tepat.

3. Subsistem Antarmuka Pengguna (Dialog Management) Pengguna dapat berkomunikasi dan memberikan perintah pada SPK melalui subsistem ini.

4. Subsistem Manajemen Berbasis-Pengetahuan (Knowledge Manager)

Subsistem optional ini dapat mendukung subsistem lain bertindak sebagai komponen yang berdiri sendiri.

Komponen sistem pendukung keputusan yang telah dipaparkan di atas dapat dilihat pada Gambar 1.

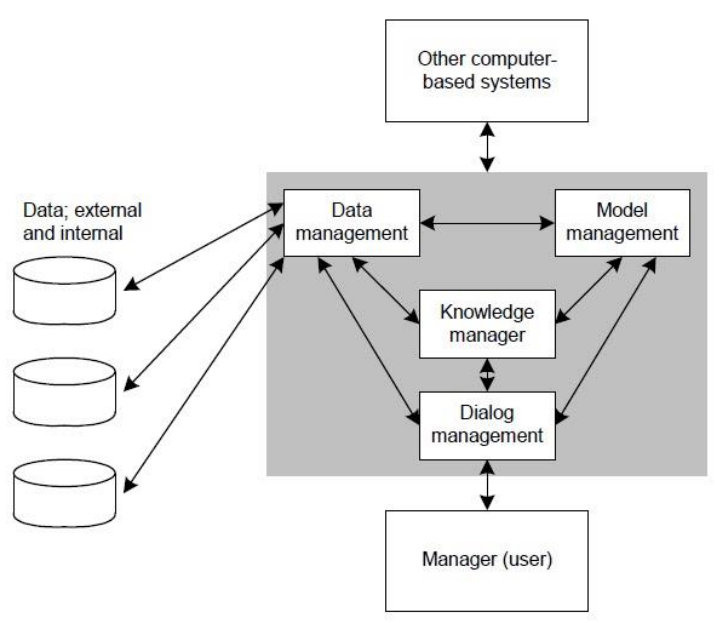

Gbr 1 Komponen sistem pendukung keputusan [10]

\section{Simple Additive Weighting (SAW)}

Metode Simple Additive Weighting (SAW) sering juga dikenal dengan istilah penjumlahan terbobot. Konsep dasar 
metode SAW adalah mencari penjumlahan terbobot dari rating kinerja pada setiap alternatif pada semua atribut. Metode SAW membutuhkan proses normalisasi matriks keputusan (X) ke suatu skala yang dapat diperbandingkan dengan semua rating alternatif yang ada [11].

\section{METODELOGI}

Tahap-tahap penelitian yang digunakan dalam penelitian ini terdiri dari analisis sistem, perancangan sistem, pembuatan sistem, pengujian sistem, dan penyimpulan seperti yang diilustrasikan pada gambar 2 .

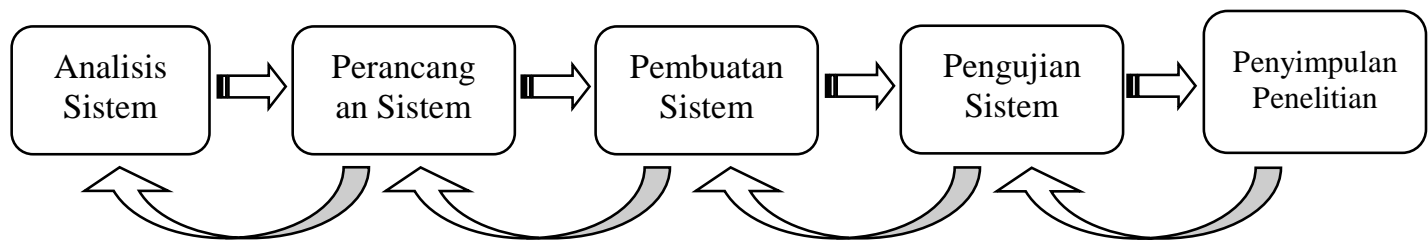

Tinjauan tahap sebelumnya/modifikasi ulang

Gbr 2 Tahap-tahap penelitian

Pada tahap analisis sistem di lakukan analisi kebututuhan sistem terkait sistem yang akan dibuat. Setelah proses analisis sistem selesai, kemudian dilakukan perancangan sistem yang meliputi perancangan basis data, perancangan antarmuka, dan perancangan proses. Tahap selanjutnya yaitu pembuatan sistem sesuai dari perancangan yang dilakukan pada tahap sebelumnya. Kemudian dilanjutkan tahap pengujian sistem untuk menguji unjuk kerja sistem dan melakukan pengambilan kesimpulan dari pengujian yang telah dilakukan.

\section{HASIL DAN PEMBAHASAN}

\section{A. Gambaran Sistem}

Sistem pendukung keputusan penerima zakat di BAZNAS kota Semarang menerima masukan berupa data alternatif mustahik. Data alternatif tersebut disimpan ke dalam database, kemudian dilakukan penghitungan SAW yang hasilnya akan ditampilkan. Data yang ditampilkan adalah nama mustahik, nilai kriteria dan nilai preferensi. Alternatif kemudian diurutkan berdasarkan nilai preferensi tertinggi ke terendah, untuk kemudian dipilih berurutan berdasarkan dana yang tersedia. Selain itu, sistem pendukung keputusan ini dapat mencetak laporan hasil akhir penerima zakat dan memberi batasan maksimal pengajuan bantuan yaitu setahun sekali perorang.

\section{B. Permodelan Data}

Hubungan antar tabel dimodelkan dengan menggunakan Entity-Relationship Diagram (ERD) yang digunakan untuk mengidentifikasi objek data dan hubungannya dengan menggunakan notasi grafis dalam perekayasaan perangkat lunak. Atribut dari masing-masing objek data digambarkan dengan menggunakan deskripsi objek data. ERD hanya berfokus pada data dengan menunjukkan jaringan data yang ada untuk suatu sistem yang diberikan. ERD dari Sistem Pendukung Keputusan Penerima Zakat dapat dilihat pada gambar 3 . 

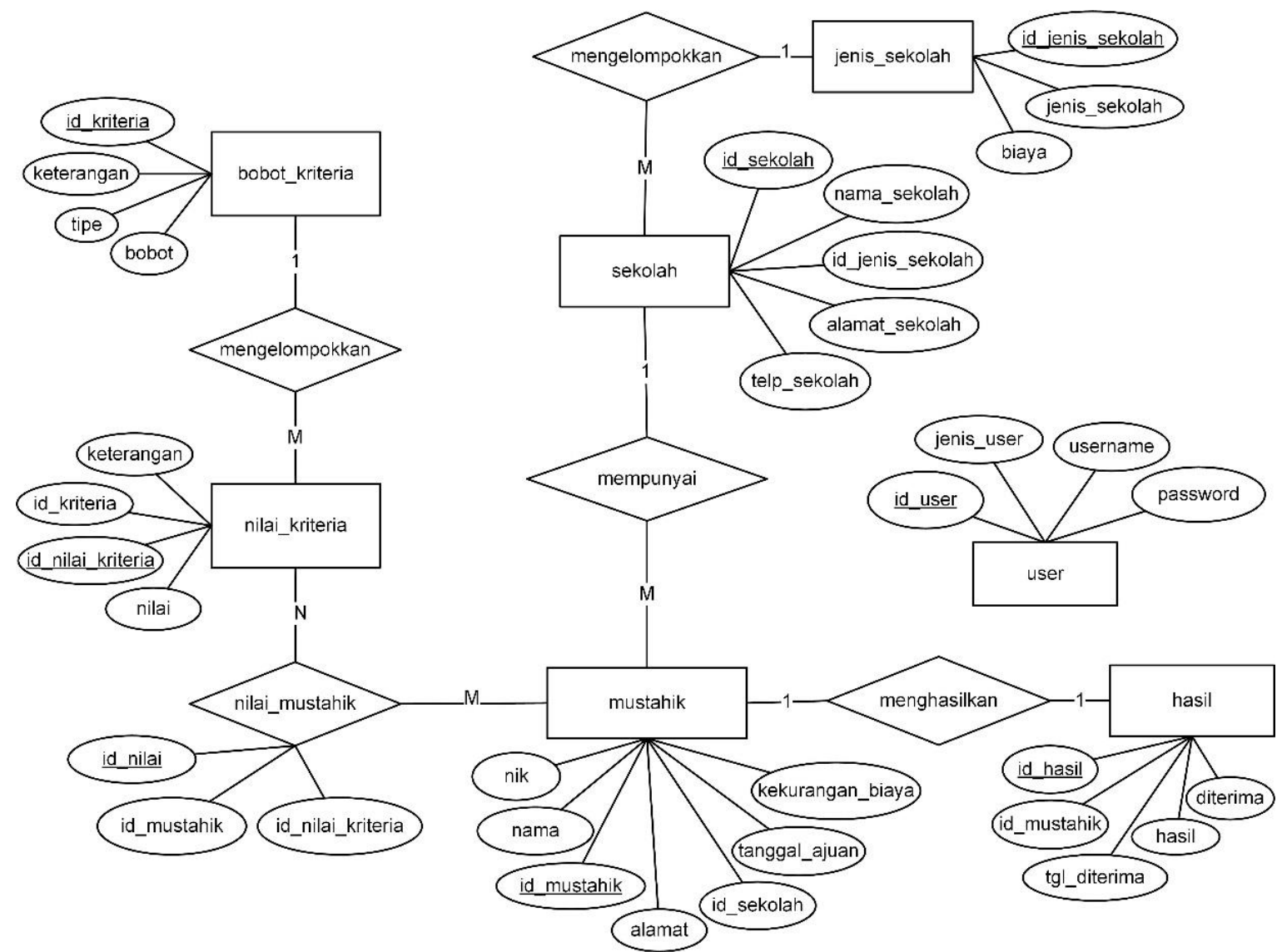

Gbr 3 ERD dari Sistem Pendukung Keputusan Penerima Zakat

\section{Perancangan Proses}

Perancangan proses pada sistem pendukung keputusan penerima zakat dibuat berdasarkan proses penghitungan yang terdapat dalam sistem. Perancangan proses dibuat dengan menggunakan flowchart. Perancangan proses secara keseluruhan dijelaskan pada gambar 4. Flowchart pada gambar 4 menggambarkan ketika pengguna telah login kedalam sistem, lalu melakukan input alternatif, nilai kriteria, dan bobot untuk dilakukan evaluasi dengan menggunakan metode SAW. Selanjutnya dilakukan proses pemilihan penerima zakat sesuai dengan dana yang tersedia. Hasil akhirnya berupa mustahik yang disetujui untuk diberi bantuan dana.

Flowchart pada gambar 5 menggambarkan proses evaluasi SAW, dimana setelah input alternatif, nilai kriteria dan bobot, sistem mencocokkan nilai alternatif (Ai) dengan nilai kriteria (Cj). Membuat matriks keputusan, lalu melakukan normalisasi matriks sesuai dengan jenis atribut kriteria, yaitu benefit dan cost. Selanjutnya nilai preferensi diperoleh dari penjumlahan dari perkalian elemen baris matriks ternormalisasi dengan bobot (W) dan melakukan perangkingan. Langkah selanjutnya melakukan proses pemilihan penerima zakat sesuai dengan dana yang tersedia seperti yang dijelaskan pada gambar 6 .

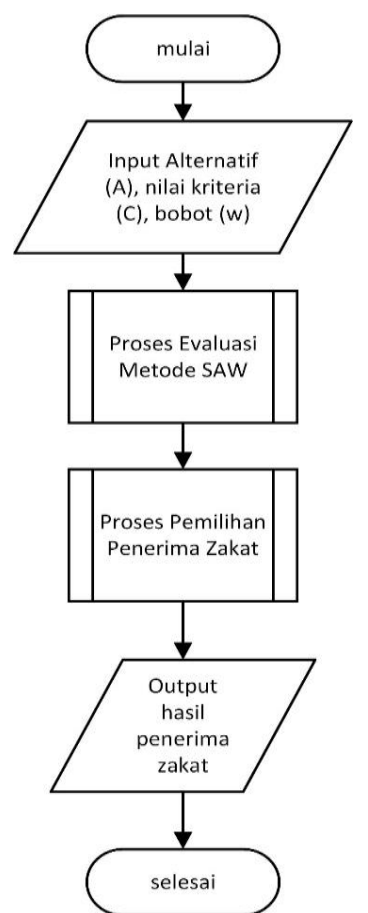

Gbr 4 Flowchart sistem pendukung keputusan penerima zakat 


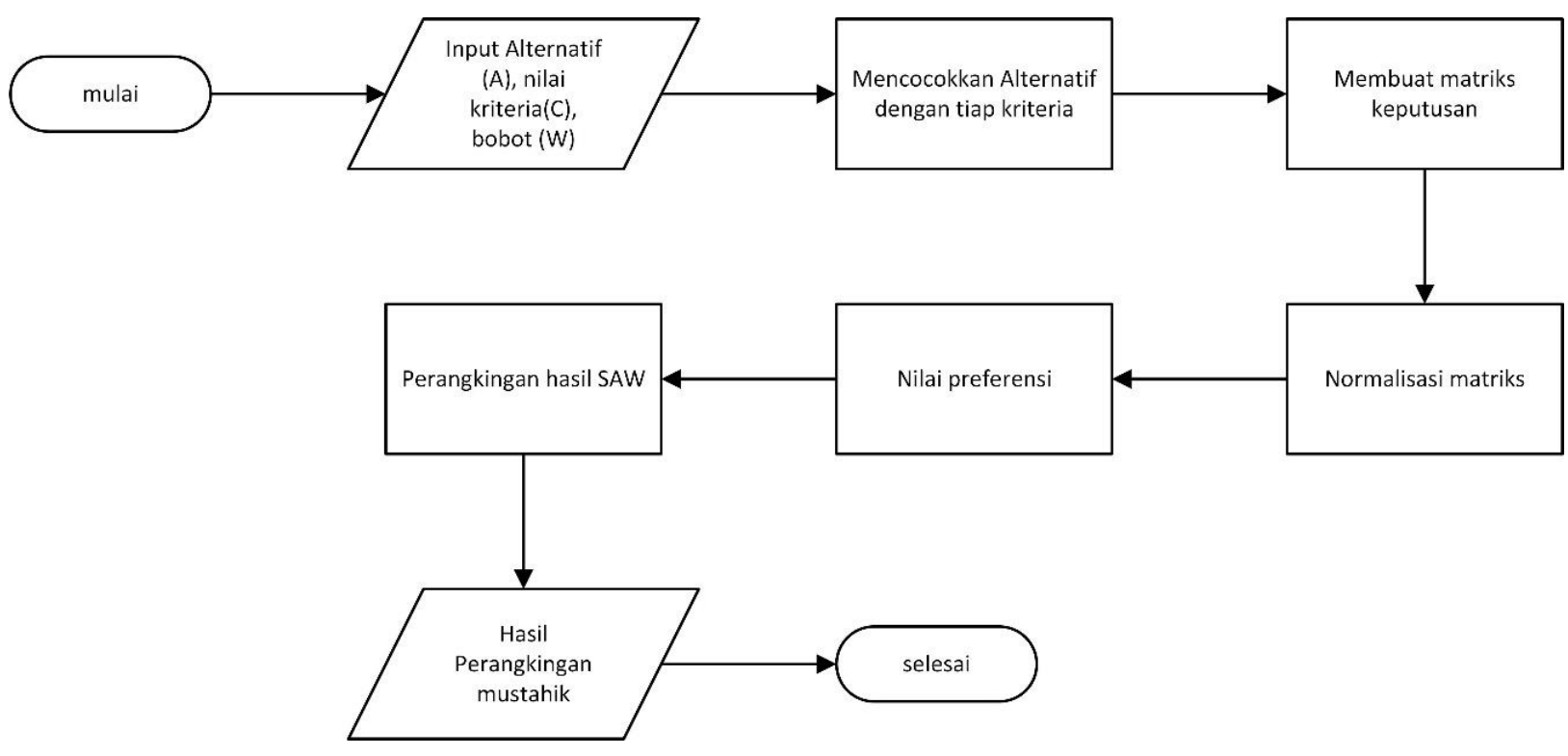

Gbr 5 Flowchart proses evaluasi SAW

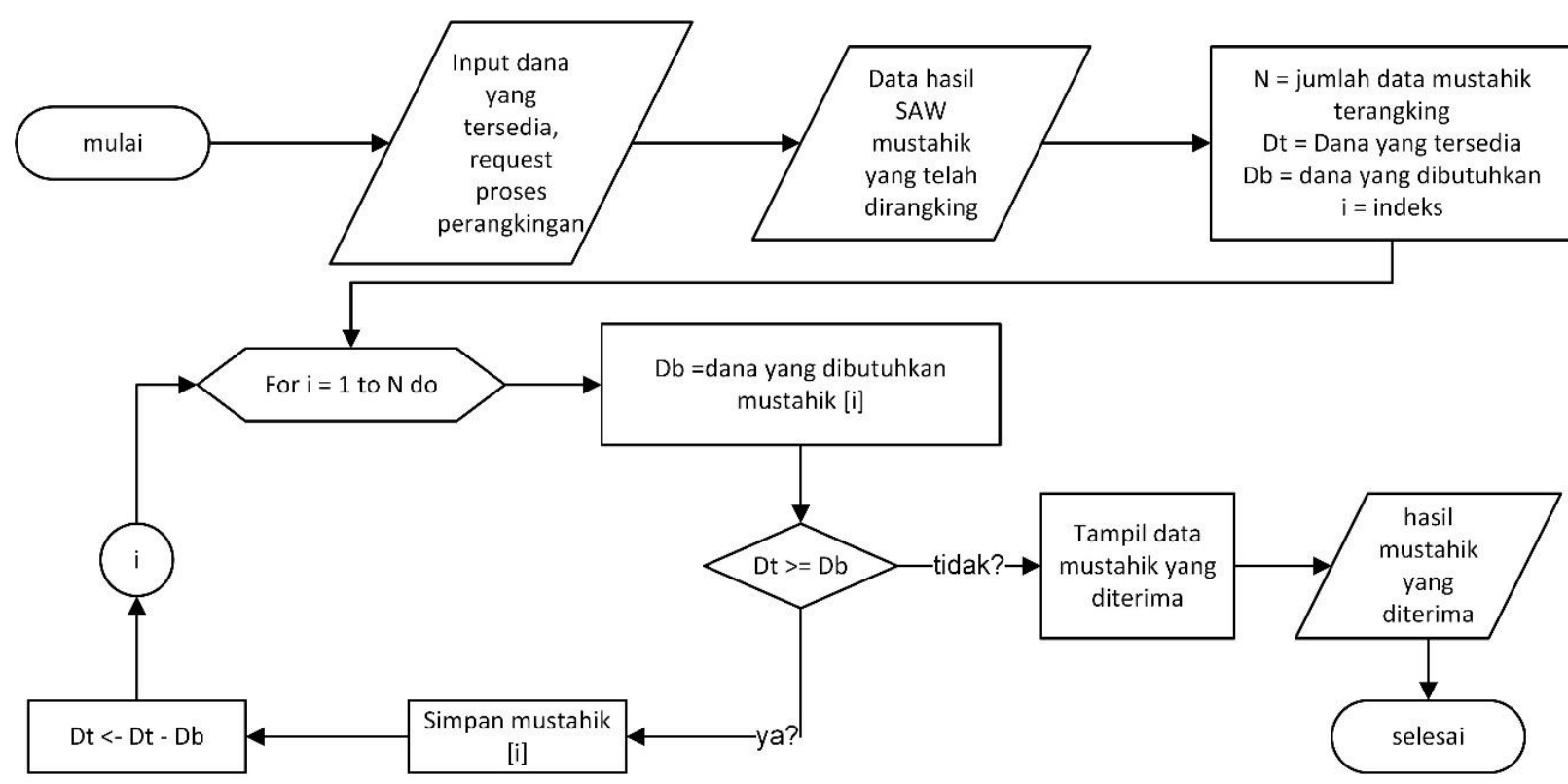

Gbr 6 Proses pemilihan penerima zakat

D. Pengujian

Pengujian dilakukan dengan perbandingan antara hasil pemilihan sistem yang dibuat/ sistem baru dengan hasil pemilihan sistem lama dari BAZNAS kota Semarang. Hasil pengujian tersebut yaitu seperti pada tabel 1 . 
TABEL 1

PERBANDINGAN HASIL PEMILIHAN SISTEM LAMA DENGAN SISTEM BARU

\begin{tabular}{|l|l|l|l|}
\hline \multicolumn{1}{|c|}{ Nama } & \multicolumn{1}{|c|}{ Sistem Baru } & \multicolumn{1}{c|}{$\begin{array}{c}\text { Sistem } \\
\text { Lama }\end{array}$} & \multicolumn{1}{c|}{ Hasil } \\
\hline Vina R. & Diterima & Diterima & Akurat \\
\hline Yuni N.A. & Ditolak & Diterima & $\begin{array}{l}\text { Tidak } \\
\text { Akurat }\end{array}$ \\
\hline Eko P. & Diterima & Diterima & Akurat \\
\hline $\begin{array}{l}\text { Andrian } \\
\text { G.P. }\end{array}$ & Diterima & Diterima & Akurat \\
\hline Dias A. & Diterima & Ditolak & $\begin{array}{l}\text { Tidak } \\
\text { Akurat }\end{array}$ \\
\hline Dicky C. & Ditolak & Ditolak & Akurat \\
\hline Bagas D. & Diterima & Diterima & Akurat \\
\hline M.Yusuf & Ditolak & Ditolak & Akurat \\
\hline Dimas A. & Diterima & Diterima & Akurat \\
\hline Tegar A.M. & Diterima & Diterima & Akurat \\
\hline Amelia R. F. & Diterima & Diterima & Akurat \\
\hline
\end{tabular}

Terdapat perbedaan dari hasil pemilihan dan total dana oleh sistem lama BAZNAS kota Semarang dengan sistem baru. Tingkat akurasi pemilihan sistem baru dengan sistem lama BAZNAS kota Semarang adalah $81 \%$. Perbedaan terjadi karena pemilihan pada sistem lama dari BAZNAS kota Semarang bedasarkan tanggal ajuan mustahik, yaitu jika terdapat mustahik yang seharusnya menerima bantuan pada bulan lalu namun tidak terpilih, maka mustahik tersebut berhak didahulukan untuk menerima bantuan pada bulan berikutnya.

\section{KESIMPULAN}

Sistem pendukung keputusan penerima zakat dengan metode SAW dengan kriteria status anak, tanggungan orangtua, pendapatan orangtua, indeks rumah dan kepemilikan harta telah di hasilkan dengan tingkat $81 \%$ jika di bandingkan dengan yang telah di terapkan oleh BAZNAS kota semarang.
Hal ini di sebabkan karena sistem bersifat objektif dan dipilih berdasarkan periode bulanan, sedangkan pada keputusan zakat di BAZNAS kota Semarang, penerima zakat diurutkan berdasarkan tanggal mustahik mengajukan bantuan.

\section{REFERENSI}

[1] I. Afrianty dan R. Umbara, "Sistem Pendukung Keputusan (SPK) Menentukan Kelayakan Calon Penerima Zakat Menerapkan MultiFactor Evaluation Process (MFEP)", Seminar Nasional Teknologi Informasi Komunikasi dan Industri (SNTIKI), Pekanbaru, pp. 87-94, 2016.

[2] R.A. Ramadhani dan J. Sulaksono , "Penentuan Penerima Zakat Dengan Metode Fuzzy", Seminar Nasional Teknologi Informasi dan Multimedia 2016, Yogyakarta, pp. 37-41, 2016.

[3] B. Arifa, "Sistem Pendukung Keputusan Penerima Bantuan Dana Zakat Menggunakan Metode Anp (Analytic Network Process) (Studi Kasus : Laznas Chevron Rumbai)", Fakultas Sains dan Teknologi, Universitas Islam Negeri Sultan Syarif Kasim Riau, 2015.

[4] I. Husnudin., " Sistem Pendukung Keputusan (SPK) menetukan Kelayakan Penerima Zakat Menggunakan metode Fuzzy C-Means", Fakultas Sains dan Teknologi, Universitas Islam Negeri Sultan Syarif Kasim Riau, 2014.

[5] H. Sulistyo, "Sistem Pendukung Keputusan Untuk Menentukan Penerima Beasiswa Di SMA Negeri 6 Pandeglang”. Jurusan Teknik Informatika Fakultas Teknik dan Ilmu Komputer, Universitas Komputer Indonesia Bandung, 2010.

[6] Arfyanti, Ita, dan E. Purwanto, "Aplikasi Sistem Pendukung Keputusan Pemberian Kelayakan Kredit Pinjaman Pada Bank Rakyat Indonesia Unit Segiri Samarinda Dengan Metode Fuzzy MADM (Multiple Attribute Decission Making) menggunakan SAW (SImple Additive Weighting)". Seminar Nasional Teknologi Informasi \& Komunikasi Terapan 2012 (Semantik 2012), pp. 119-124, 2012.

[7] Departemen Agama Republik Indonesia, Al-Quran dan terjemahannya". Pustaka Agung Harapan. Surabaya, 2006.

[8] Kemensos, "Peraturan Kementrian Sosial Republik Indonesia nomor 143/ HUK / 2013 Tentang Penetapan Kriteria dan Pendataan Orang Fakir Miskin dan Tidak Mampu”, Kemensos Jakarta, 2013.

[9] E. Turban, Aronson dan E. Jay , "Decision Support System and Intelligent System". Edisi 7, Edisi Bahasa Indonesia, Andi Offset. Yogyakarta, 2005.

[10] I. Subakti, "Sistem Pendukung Keputusan". Institut Teknologi Sepuluh November. Surabaya, 2002.

[11] S. Kusumadewi, S. Hartati, A. Harjoko dan R. Wardoyo, "Fuzzy MultiAtribut Decision Making”, Penerbit Graha Ilmu, Yogyakarta, 2006. 